\title{
HAK ANAK DALAM SISTEM PERADILAN PIDANA ANAK DI INDONESIA
}

\author{
Ramdani \\ Program Magister Ilmu Hukum \\ Pascasarjana Universitas Islam Malang \\ Email : aramdani1995@gmail.com
}

\begin{abstract}
Abstrak
Penelitian ini membahas tentang "Hak Anak Dalam Sistem Peradilan Pidana Anak di Indonesia". Penelitian ini bertujuan untuk mengentahui, menganalisis dan membahasn konsep serta bentuk dari hak anak dalam sistem peradilan pidana anak di Indonesia. Penelitian ini merupakan penelitian normativ dengan menggunakan pendekatan studi kepustakaan dengan menelaah, meneliti dan mengkaji perundang-undangan yang membahas tentang hak anak baik secara konsep maupun bentuk. Hasil dari penelitian ini secara garis besar dapat disimpulkan bahwa anak dalam dalam perkara pidana mendapat jaminan perlindungan hukum dalam berbagai bentuk seperti jaminan keselamatan baik fisik, mental maupun sosial dan memiliki akses terhadap informasi mengenai perkembangan perkara. Anak harus mendapatkan haknya berdasarkan kepentingan terbaik anak penghargaan terhadap anak. Jaminan perlindungan yang didapat tidak hanya dari Undang-undang No 11 tahun 2012 tentang sistem peradilan pidana anak namun juga dari Undang-undang No 13 tahun 2006 tentang perlindungan saksi dan korban. Negara dalam hal ini pemerintah dan aparatur penyelenggara memperhatikan implementasi yang efektif dengan pertimbangan kepentingan terbaik anak.
\end{abstract}

Kata kunci: Sistem peradilan pidana anak, perlindungan anak, hak anak

\begin{abstract}
This research discusses "Children's Rights in the Child Criminal Justice System in Indonesia". This study aims to identify, analyze and discuss the concepts and forms of children's rights in the juvenile justice system in Indonesia. This research is a normative study using a literature study approach by examining, researching and examining laws that discuss children's rights both in concept and form. The results of this study can be broadly concluded that children in criminal cases receive legal protection guarantees in various forms such as safety guarantees both physically, mentally and socially and have access to information regarding case developments. Children must get their rights based on the best interests of the child and respect for the child. The guarantee of protection is obtained not only from Law No. 11 of 2012 concerning the juvenile criminal justice system but also from Law No. 13 of 2006 concerning the protection of witnesses and victims. The state in this case the government and the apparatus organizers pay attention to effective implementation with consideration of the best interests of children.
\end{abstract}

Keywords: Child criminal justice system, child protection, children's rights 


\section{PENDAHULUAN}

Indonesia sebagai negara telah mengakui hak-hak anak di dalam konstitusinya. Pengakuan tersebut tertuang di dalam Undang-Undang dasar 1945 Pasal 28B ayat (2) yang mengatur bahwa setiap anak berhak atas keberlangsungan hidup, tumbuh dan berkembang serta berhak atas perlindungan diri dari kekerasan dan diskriminasi. Pasal tersebut merupakan salah satu alat yang dapat dipergunakan oleh negara untuk membantu penanganan permasalahan yang berkaitan dengan hak anak dan dikelompokkan sebagai pasal yang membahas tentang hak asasi manusia. Sebagai subyek hukum dan aset bangsa, anak memiliki posisi strategis dan merupakan penerus keberlangsungan dari suatu bangsa. Berdasarkan hal tersbut, setiap anak perlu untuk mendapatkan pembinaan dan perlindungan dan kesempatan untuk dapat secara optimal untuk berkembang.. ${ }^{1}$

Pada hakekatnya, dunia internasional telah memberikan perhatian khusus terhadap hak anak. Hal ini dapat dilihat dari banyaknya instrumen internasional tentang hak anak. Di indonesia, salah satu implementasi pengakuan hak anak adalah dengan dibentuknya undang-undang yang secara khusus diperuntukkan pada pengaturan sistem peradilan anak. Tujuan dibentuknya dari undang-undang ini adalah memberikan jaminan terhadap perlindungan hak-hak anak sekalipun seorang anak berada dalam kondisi terburuk seperti melanggar ketentuan dan norma hukum pidana yang menegakannya menggunakan instrumen hukum pidana. Berdasarkan hal tersebut kemudian diupayakan lahirnya sebuah payung hukum berupa undang-undang nomor 3 tahun 1997 tentang pengadilan anak.

Namun seiring perjalnan waktu dan dalam proses perkembangannya, undang-undang nomor 3 tahun 1997 yang mengatur tentang pengadilan anak sudah dianggap tidak lagi sejalan dengan kondisi dan perkembangan masyarakat. Undang-undang tersebut dianggap belum mampu mengakomodir kebutuhan kebutuhan dari masyarakat mengenai perlindungan yang komprehensif terhadap anak yang berada dalam posisi berhadapan dengan hukum sehingga memerlukan adanya sebuah revisi atau perbaikan. Berdasarkan hal tersebut, pemerintah bersama dengan DPR pada tanggal 30 Juli 2012 telah mengesahkan undangundang baru sebagai pengganti yaitu nomor 11 tahun 2012 tentang sistem peradilan pidana anak (UU SPPA). Undang-undang tersebut membawa paradigma baru dalam penegakan hukum terhadap anak berhadapan hukum (sebelumnya disebut dengan istilah anak nakal).

Dalam perspektif hukum pidana, seorang anak yang melakukan sebuah tindak pidana atau sebuah tindakan yang melanggar norma hukum perlu untuk dapat ditafsirkan sebagai bentuk dari ketidakmampuan akal, moralitas, fisik atau mentalitas yang terdapat pada diri anak dan dipengaruhi oleh faktor kodrat. Jika dipandang dari perspektif psikologis, terganggunya proses tumbuh dan berkembangnya seorang anak yang bermasalah cenderung muncul dari adanya tindakan yang sewenang-wenang terhadap anak tersebut. Dengan begitu kompleksnya berbagai bentuk permasalahan yang memiliki kaitan dengan pentingnya perlindungan bagi seorang anak yang sedang mengalami permasalahan atau keterlibatan dengan hukum pada hakekatnya memerlukan

${ }^{1}$ Maidin Gultom, 2008, Perlindungan Hukum Terhadap Anak dalam Sistem Peradilan

Pidana Anak di Indonesia, Bandung, Refika Aditama, hal. 1 
upaya khusus berkolaborasi antar berbagai pihak sebagai upaya dalam menyelamatkan generasi penerus bangsa.

Dalam konsep dan penerapannya, pendekatan restoratif justice telah menjadi hal penting untuk diperhatikan berkaitan dengan Undang-undang Sistem Peradilan Pidana Anak dimana dalam penerapannya, proses diversi merupakan upaya yang perlu untuk lebih diutamakan dalam rangka penyelesaian suatu kasus tindak pidana yang memiliki kaitan dengan anak. Restrorative Justice sebagai prinsip yang perlu untuk ditegakkan dalam pelaksanaan proses diversi terhadap tindak pidana yang bersinggungan dengan anak telah diatus dengan tegas dan jelas di dalam undang undang sistem peradilan anak secara yuridis formil. Namun pada beberapa kasus terkadang terdapat kebimbangan dalam menempatkan hak anak dalam proses hukum yang sedang dijalaninya. Hal tersebut cenderung terjadi pabila perkara yang dihadapi menempatkan keseluruhan aspek adalah anak baik sebagi korban, saksi atau bahkan pelaku. Penempatan hak anak tanpa mengenyampingkan keadilan menjadi hal yang cenderung sulit dirumuskan.

\section{METODE PENELITIAN}

Penelitian ini menggunakan pendekatan yuridis normatif dan pendekatan empiris. Merujuk pada tipologi penelitian menurut Soerjono Soekanto menjelaskan bahwa studi pendekatan terhadap hukum yang normatif terhadap hukum yang normatif mengkonsepsikan hukum sebagai norma, kaidah, peraturan dan perundangundangan yang berlaku pada suatu waktu dan tempat tertentu sebagai produk dari suatu kekuasaan Negara tertentu yang berdaulat. Permasalahan pokok dalam penelitian ini adalah tentang jaminan perlindungan hak anak dalam sistem peradilan pidana anak di Indonesia. Pendekatan normatif dimaksudkan untuk menggali dan mengkaji peraturan perundang-undangan sebagai dasar berpijak dalam meneliti dalam persoalan.

\section{PEMBAHASAN}

Hak-hak anak pidana diatur dalam Pasal 22 ayat (1) UndangUndang No. 12 tahun 1995 tentang Pemasyarakatan, yang menyatakan bahwa seorang anak pidana memperoleh hak-hak sebagaimana dimaksud dalam Pasal 14 Kecuali huruf $\mathrm{g}$, dengan demikian hak-hak anak tersebut meliputi:

a. melakukan ibadah sesuai dengan agama atau kepercayaannya;

b. mendapat perawatan, baik perawatan rohani maupun jasmani;

c. mendapatkan pendidikan dan pengajaran;

d. mendapatkan pelayanan kesehatan dan makanan yang layak;

e. menyampaikan keluhan;

f. mendapatkan bahan bacaan dan mengikuti siaran media massa lainnya yang tidak dilarang;

g. menerima kunjungan keluarga, penasihat hukum, atau orang tertentu lainnya;

h. mendapatkan pengurangan masa pidana (remisi);

i. mendapatkan kesempatan berasimilasi termasuk cuti mengunjungi keluarga;

j. mendapatkan pembebasan bersyarat;

k. mendapatkan cuti menjelang bebas; dan 
1. mendapatkan hak-hak lain sesuai dengan peraturan perundang-undangan yang berlaku

Dalam Undang-Undang 39 Tahun 1999 tentang Hak Asasi Manusia, hak anak-anak yang dirampas kebebasannya diatur dalam Pasal 66, yakni meliputi:

a. Hak untuk tidak dijatuhi hukuman mati atau hukuman seumur hidup.

b. Hak untuk mendapatkan perlakuan secara manusiawi dan dengan memperhatikan kebutuhan pengembangan pribadi sesuai dengan usianya dan harus dipisahkan dari orang dewasa, kecuali demi kepentingannya.

c. Hak untuk memperoleh bantuan hukum atau bantuan lainnya secara efektif dalam setiap tahapan upaya hukum yang berlaku.

d. Hak untuk membela diri dan memperoleh keadilan di depan Pengadilan Anak yang objektif dan tidak memihak dalam sidang yang tertutup untuk umum.

Selanjutnya berdasarkan ketentuan yang temuat dalam Pasal 16 ayat (3) Undang-Undang No. 23 Tahun 2002 tentang perlindungan anak dinyatakan bahwa penangkapan, penahanan, atau tindak pidana penjara anak hanya dilakukan apabila sesuai dengan hukum yang berlaku dan hanya dapat dilakukan sebagai upaya terakhir. Selain itu, dalam Pasal 17 dijelaskan lebih lanjut mengenai hak dari anak yang dirampas kebebasannya, yakni meliputi:

a. Mendapatkan perlakuan secara manusiawi dan penempatannya dipisahkan dari orang dewasa;

b. Memperoleh bantuan hukum atau bantuan lainnya secara efektif dalam setiap tahapan upaya hukum yang berlaku; dan

c. Membela diri dan memperoleh keadilan di depan pengadilan anak yang objektif dan tidak memihak dalam sidang tertutup untuk umum.

Selain memperoleh hak-hak diatas, seorang anak yang berhadapan dengan hukum juga hak mendapatkan perlindungan khusus seperti yang yang diatur dalam ketentuan Pasal 64 Undang-Undang No. 23 Tahun 2002 tentang Perlindungan Anak, yakni:

a. Perlakuan atas anak secara manusiawi sesuai dengan martabat dan hak-hak anak.

b. Penyediaan petugas pendamping khusus anak sejak dini;

c. penyediaan sarana dan prasarana khusus;

d. penjatuhan sanksi yang tepat untuk kepentingan yang terbaik bagi anak;

e. pemantauan dan pencatatan terus menerus terhadap perkembangan anak yang berhadapan dengan hukum;

f. pemberian jaminan untuk mempertahankan hubungan dengan orang tua atau keluarga; dan

g. perlindungan dari pemberitaan identitas melalui media massa dan untuk menghindari labelisasi.

Secara lebih lanjut, dalam Pasal 4 (1) Undang-Undang No 11 Tahun 2012 tentang Sistem Peradilan Pidana Anak, dinyatakan bahwa anak yang sedang menjalani masa pidana berhak untuk:

a. mendapat pengurangan masa pidana;

b. memperoleh asimilasi;

c. memperoleh cuti mengunjungi keluarga; 
d. memperoleh pembebasan bersyarat; e. memperoleh cuti menjelang bebas;

e. memperoleh cuti bersyarat; dan

f. memperoleh hak lain sesuai dengan ketentuan peraturan perundangundangan

Secara garis besar, hak anak dalam sistemperadilan pidana anak di Indonesia yang tehimpun melalui berbagai undang-undang dan peraturan yang melindunginga dapat disimpulkan sebagai berikut.

\section{a. Hak Mendapatkan Pendampingan}

Hal lain berkaitan dengan keselamatan yaitu keamanan dan kenyamanan anak yang menjadi saksi diatur pula dalam Undang-undang No. 11 Tahun 2012. Undang-undang ini mengatur tempat khusus yang sewaktuwaktu dibutuhkan anak sebagai saksi dalam proses peradilan pada Pasal 91, yaitu: (1) Berdasarkan pertimbangan atau saran Pembimbing Kemasyarakatan, Pekerja Sosial Profesional atau Tenaga Kesejahteraan Sosial atau Penyidik dapat merujuk Anak, Anak Korban, atau Anak Saksi ke instansi atau lembaga yang menangani pelindungan anak atau lembaga kesejahteraan sosial anak. (4) Anak Korban dan/atau Anak Saksi yang memerlukan pelindungan dapat memperoleh pelindungan dari lembaga yang menangani pelindungan saksi dan korban atau rumah perlindungan sosial sesuai dengan ketentuan peraturan perundang- undangan Pada Ayat (1) di atas, diketahui bahwa anak yang menjadi saksi dalam perkara pidana dapat dititipkan kepada lembaga perlindungan atau lembaga kesejahteraan sosial anak. Hal ini dapat dilakukan karena hasil pengamatan dari para pendamping anak tersebut melihat bahwa anak saksi yang bersangkutan memang memerlukan suatu perlindungan khusus. Demikian juga pada Ayat (4), penyidik maupun pihak lain dapat meminta lembaga peradilan untuk menyediakan rumah perlindungan saksi maupun perlindungan sosial di suatu tempat khusus. Setiap anak berhak mendapat pelindungan dari tindakan yang merugikan, menimbulkan penderitaan mental, fisik dan sosial.

\section{b. Hak Didampingi Pembela}

Pada prinsipnya, keterangan yang dapat mengarah pada terungkapnya identitas seorang pelanggar hukum berusia muda tidak dapat dipublikasikan. Hal ini dikarenakan anak-anak tidak dapat menjadi subyek hukum badan. Setiap anak harus diperlakukan sebagai subyek yang belum terbukti bersalah. Anak juga berhak dibela oleh seorang ahli. Setiap anak berhak untuk sidang tertutup, hanya dikunjungi orang tua atau wali atau orang tua asuhnya, petugas sosial, saksi dan orang-orang yang berkepentingan, mengingat kehormatan/ kepentingan anak dan keluarga, maka wartawanpun tidak dibenarkan ikut serta, kecuali mendapat ijin dari hakim, dengan catatan identitas anak tidak boleh diumumkan. Bantuan hukum berarti suatu bentuk bantuan pada tersangka/terdakwa anak yang berupa nasihat hukum.

Sesuai dengan Pasal 51 dan Pasal 52 Undang-Undang Pengadilan Anak bahwa setiap anak sejak ditangkap atau ditahan, berhak mendapat bantuan hukum dari seorang atau lebih penasehat hukum. Bantuan hukum itu diberikan selama dalam waktu dan pada setiap tingkat pemeriksaan menurut tata cara yang ditentukan. Pejabat yang melakukan penangkapan atau penahanan (penyidik, penuntut umum atau hakim) wajib memberitahukan kepada tersangka/ terdakwa, orang tuanya, walinya atau orang tua asuhnya 
mengenai hak memperoleh bantuan hukum itu. Setiap anak yang ditahan berhak berhubungan langsung dengan penasihat hukum dengan diawasi tanpa didengar oleh pejabat yang berwenang. Penasihat hukum wajib memperhatikan kepentingan anak dan kepentingan umum dalam memberikan bantuan hukum kepada anak serta berusaha agar suasana kekeluargaan tetap terpelihara dan peradilan berjalan lancar.

c. Hak Menjalani Peradilan dalam Situasi Khusus untuk Anak

Menurut Undang-undang No. 11 Tahun 2012 tentang Sistem Peradilan Pidana Anak Pasal (1) Ayat (5) disebutkan bahwa anak saksi adalah seseorang dengan pembatasan usia di bawah 18 tahun yang dapat memberikan keterangan guna kepentingan penyidikan, penuntutan, dan pemeriksaan di sidang pengadilan tentang suatu perkara pidana yang didengar, dilihat, dan/atau dialaminya sendiri. Secara psikologis,anak akan mengalami tekanan baik pada posisinya sebagai saksi, korban maupun pelaku kejahatan. Sehingga dalam Undang-undang perlindungan anak diatur mengenai anak yang membutuhkan perlindungan khusus, siantaranya adalah anak yang berhadapan dengan hukum

Beberapa hak anak yang terkait dengan anak yang membutuhkan perlindungan khusus bidang hukum antara lain:

1) Perlindungan Psikologis berupa Pendampingan Undang-undang No. 11 Tahun 2012 tentang Sistem Peradilan Pidana Anak memberikan perlindungan kenyamanan kepada anak yang menjadi saksi dalam peradilan pidana anak. Pada Pasal 18 disebutkan bahwa : Dalam menangani perkara Anak, Anak Korban, dan/atau Anak Saksi, Pembimbing Kemasyarakatan, Pekerja Sosial Profesional dan Tenaga Kesejahteraan Sosial, Penyidik, Penuntut Umum, Hakim, dan Advokat atau pemberi bantuan hukum lainnya wajib memperhatikan kepentingan terbaik bagi Anak dan mengusahakan suasana kekeluargaan tetap terpelihara. Dengan pasal tersebut tampak bahwa anak mendapat hak-hak secara psikologis. Anak bisa didampingi oleh seorang ahli yang dikehendakinya. Ahli dalam bidang penanganan hukum seperti pembimbing kemasyarakatan, pekerja sosial profesional dan tenaga kesejahteraan sosial bisa secara aktif ikut mendampingi seorang anak yang menjadi saksi ketika menjalani proses kesaksian dalam suatu keperluan peradilan pidana.

2) Anak bebas memilih pendamping yang dipercayanya. Selain daripada itu, permintaan hak untuk didampingi juga dijamin melalui undang-undang tersebut pada Pasal (23) Ayat (2) yang menyatakan "Dalam setiap tingkat pemeriksaan, Anak Korban atau Anak Saksi wajib didampingi oleh orang tua dan/atau orang yang dipercaya oleh Anak Korban dan/atau Anak Saksi, atau Pekerja Sosial.”. Dalam bagian penjelasan pasal tersebut, diterangkan bahwa yang dimaksud dengan "pemberi bantuan hukum lainnya" adalah paralegal, dosen, dan mahasiswa fakultas hukum sesuai dengan Undang-Undang tentang Bantuan Hukum. Suasana kekeluargaan misalnya suasana yang membuat Anak nyaman, ramah Anak, serta tidak menimbulkan ketakutan dan tekanan.

3) Proses pengambilan kesaksian dilakukan dalam situasi non-formal Perlindungan khusus pada peradilan pidana anak di atas kemudian 
diperkokoh dengan bentuk perlindungan lainnya di Pasal (22) yang menyatakan "Penyidik, Penuntut Umum, Hakim, Pembimbing Kemasyarakatan, Advokat atau pemberi bantuan hukum lainnya, dan petugas lain dalam memeriksa perkara Anak, Anak Korban, dan/atau Anak Saksi tidak memakai toga atau atribut kedinasan". Kewajiban melepaskan seragam kedinasan ketika melakukan proses peradilan pada anak sebagai saksi adalah demi perlindungan anak dari sisi psikologis agar anak tidak merasa tegang karena merasa berhadapan dengan aparat penegak hukum. Suasana tanya jawab dilaksanakan secara kekeluargaan, sehingga anak merasa aman dan tidak takut, dan harus menggunakan bahasa yang dimengerti oleh anak.

\section{PENUTUP}

Anak yang perposisi sebagai saksi dalam perkara pidana akan mendapatkan jaminan perlindungan hukum yakni berupa jaminan keselamatan baik fisik, mental, maupun sosial dan memiliki akses terhadap informasi mengenai perkem- bangan perkara. Anak sebagai saksi harus mendapatkan haknya berdasarkan kepentingan terbaik anak dan penghargaan terhadap anak. jaminan perlindungan yang didapatkan tidak hanya dari Undang- Undang No.11 tahun 2012 tentang Sistem peradilan pidana anak, namun juga dari UndangUndang nomer 13 tahun 2006 tentang perlindungan saksi dan korban. Negara dalam hal ini pemerintah dan aparatur penyelenggara peradilan yang bertanggung jawab menegakkan Undang- undang 11 tahun 2012, agar memperhatikan impelemtasi yang efektif dengan pertimbangan kepentingan terbaik anak, anggaran yang dibutuhkan dalam penegakan, perspektif para penegak hukum

\section{DAFTAR PUSTAKA}

Abdulkadir Muhammad. 2004. Hukum dan Penelitian Hukum. Citra Aditya Bakti. Bandung.

Achmad Ali. 2002. Keterpurukan Hukum di Indonesia. Ghalia Indonesia, Jakarta. Andi Hamzah. 1986. Perlindungan Hak-hak Asasi Manusia dalam Kitab UndangUndang Hukum Acara Pidana. Bandung: Binacipta.

Apong Herlina dkk. 2004. Perlindungan Terhadap Anak Yang Berhadapan Dengan Hukum Manual Pelatihan Untuk Polisi, Jakarta: POLRI UNICEF.

Departemen Pendidikan dan Kebudayaan Republik Indonesia. 2005. Pedoman Umum Ejaan Bahasa Indonesia yang Disempurnakan dan Pedoman Umum Pembentukan Istilah. Get. Ke VII. Bandung: Pustaka Setia.

Kenneth Polk. 2003. "Juvenile Diversion in Australia: A National Review". Sydney Australia. Departement of Juvenile Justice and Held.

Kusnardi, Moh., dan Ibrahim, Harmaily. 1988. Pengantar Hukum Tata Negara Indonesia. Jakarta: PSHTN FH UI dan Sinar Bakti.

M. Hassan Wadong. 2012. Advokasi dan Hukum Perlindungan Anak. Grasindo. Jakarta.

M. Joni dan Zulchaina Z. Tanamas. 1995. Aspek Hukum Perlindungan Anak dalam Perspektif Konvensi Hak Anak. Bandung. Citra Aditya Bakti.

Made Ayu Citra Mayasari. 2012. Diversi Dalam Sistem Peradilan Pidana Anak di Indonesia. Tesis. Universitas Udayana 
Penjelasan umum Undang-Undang Nomor 11 Tahun 2012 tentang Sistem Peradilan Pidana Anak.

Ramdani, R., Nasution, A. P., Ramanda, P., \& Sagita, D. D. 2020. Strategi kolaborasi dalam manajemen pelayanan bimbingan dan konseling di sekolah. Educational Guidance and Counseling Development Journal. III(1), 1-7. DOI: http://dx.doi.org/10.24014/egcdj.v3i1.9398

Ramdani,R., Rofiqah,T., Khairat, I., Saragi, M.P.D., Saputra, R. 2020. The Role Of School Counselors To Helping Student in Puberty Through The Collaborative Paradigm. Enlighten. https://doi.org/10.32505/enlighten.v3i1

Romli Atmasasmita. 2003. Peradilan Anak di Indonesia. Bandung: Mandar Maju.

Ruben Achmad. 2005. Upaya Penyelesaian Masalah Anak yang Berkonflik dengan Hukum di Kota Palembang. dalam Jurnal Simbur Cahaya Nomor 27 Tahun X. Januari.

Setya Wahyudi. 2011. Implementasi Ide Diversi dalam Pembaruan Sistem Peradilan Pidana Anak di Indonesia. Yogyakarta. Genta Publishing.

Soerjono Soekanto.1986. Pengantar Penelitian Hukum. UI Press, Jakarta.

Tri Andirsman. 2005. Delik-Delik Luar KUHP: Tindak Pidana KOrupsi dan Pencucian Uang.

Tri Novita Sari Manihuruk. 2016. Perlindungan terhadap anak korban tindak pidana pedofilia. Jurnal Law Revorm. Universitas Diponegoro

Undang-undang Nomor 11 Tahun 2012 tentang Sistem Peradilan Pidana Anak.

Wadong, Maulana Hasan. 2000. Advokasi dan Hukum Perlindungan Anak. Grasindo. Jakarta.

Wagiati Soetodjo. 2006. Hukum Pidana Anak. Bandung. Refika Editama.

Wirjono Projodikoro.1974. Hukum Acara Pidana di Indonesia. Sumur. Bandung. 